\title{
Understanding the 2018 Same-Sex Marriage Referendum in Taiwan
}

\author{
Chin Shen \\ Ph.D. Candidate \\ Graduate School of Core Ethics and Frontier Sciences \\ Ritsumeikan University \\ 56-1 Toji-in Kitamachi, Kita-ku, Kyoto \\ Japan 603-8577
}

\begin{abstract}
This paper analyzes Taiwan's referendum on same-sex marriage and related possible disputes and problems. It discusses the shortcomings of the Referendum Act's content. First, according to the results of the referendum, same-sex marriage in Taiwan is regulated by special regulations, but once the referendum's content is examined, there remain questions and unclear points as to whether the present same-sex marriage law is consistent with the assurance of human rights and the promotion of social diversity. Second, there are still deficiencies and flaws that need to be reviewed and revised in the current Referendum Act. It is not clear whether the present law can promote communication and understanding between different groups in order to maintain society's structural stability, equality and justice. This paper argues that we need to bring the opposite parties to communicate and seek mutual respect, to recognize and tolerate differences within society. This democratic process is the most important aspect of the spirit of referendum.
\end{abstract}

Keywords: same-sex marriage; LGBT; sexual orientation; social changes; gender; referendum.

\section{Same-sex Marriage Referendum}

On May $24^{\text {th }}, 2017$, the Justice announced the constitutional Interpretation No.748 "Declaration of Freedom of Same-Sex Marriage", pointing out that the Civil Code prohibition of same-sex marriage was unconstitutional, and required parliament to introduce legislation (or amendment) within two years after the release of the explanatory ruling to correct the situation. As to the legislative method, as to how this should be done is not clearly defined ${ }^{2}$ in the Justice statement. In view of this, the "Coalition for the Happiness of our Next Generation" " (hereinafter referred to as the "CHNG") proposed three referendums ${ }^{4}$ to the "Central Election Commission" of Taiwan (hereinafter referred to as the "CEC") on January 24, 2018: 1) Marriage definition referendum (Case 10): "Do you agree that marriage defined in The Civil Code should be restricted to the union between one man and one woman?"; 2) Gender equity education referendum (Case 11): "Do you agree that the Ministry of Education should not implement the Enforcement Rules for Gender Equity Education Act in elementary and middle schools?". This second referendum proposition does not concern same sex marriage directly, but it is against legislation concerning gay and LGTB education indicating that the CHNG's intention was to opposed gay and LGTB rights in general; 3 ) Regulation of same-sex unions referendum (Case 12): "Do you agree to the protection of the rights of same-sex couples in co-habitation on a permanent basis in ways other than changing of the Civil Code?". All three were also known as the "Love home referendum".

In response, those who pursue equal rights in marriage also proposed "equal rights referendums" to oppose the "Love home referendum". The main texts included are: 1) The equality of marriage rights referendum (Case 14): "Do you agree that the protection of same-sex marital rights should be included in the Civil Code (as amended)?"; 2) The gender equity education referendum (Case 15): "Do you agree that the gender equity education be specified for each stage of national education under the "Gender Equality Education Act" and that affective education, gender education, the education on LGBT etc. be included in the curriculum?".All these different referendum propositions were approved by the CEC (Central Election Commission).

\footnotetext{
${ }^{1}$ J.Y. Interpretation No.748 (2017/05/24).

${ }^{2}$ The current provisions of the Civil Code do not forbid same-sex marriage explicitly, however, articles do not include the marriage of two same-sex individuals. According to the Interpretation No.748, same-sex marriage in Taiwan can, or rather must be legalized.

3下一代幸福聯盟(CHNG), https://taiwanfamily.com/category/hearings, accessed 13 Auguest 2020.

${ }^{4}$ 1)Marriage definition referendum: https://web.cec.gov.tw/central/cms/HearingNotice/27003; 2) Gender equity education referendum: https://web.cec.gov.tw/central/cms/HearingNotice/27038; 3) Form other than marriage to regulate same-sex unions referendum: https://web.cec.gov.tw/central/cms/HearingNotice/27029, accessed 13 Auguest 2020.
} 
The referendum were held on November $24^{\text {5and }}$ the results were known on December $1^{6:}$ Cases $10,11,12$ passed, cases 14 \& 15 failed. That is, all three CHNG proposals were accepted, the counter proposals trying to defend Gay and LGTB rights rejected. The same-sex union "special-law" came into force on May 24, 2019, exactly two years after constitutional interpretation No. 748.

Cases 10, 12 and14 referendum involve a dispute about the legislative approach to same-sex marriage. The controversy mainly comes from paragraph 17 of Interpretation No.748, which points out that "the different ways to achieve equal protection and freedom for different parties of same-sex couples wishing to establish a permanent and exclusive relationship of intimacy for the purpose of cohabitation (for example, revising the Marriage Chapter of the Civil Code, drawing up a specific chapter in the Civil Code, formulating a special law for same-sex marriage or other forms), are all within the scope of law".

In view of this, the CHNG hoped (and succeeded) to achieve two goals by its referendum proposals:

1) that Civil marriage be limited to a union between a man and a woman.

2) that a special law be established to regulate and guarantee same-sex marriage.

The analysis of this article focuses on two issues: 1) The content of the referendum proposals; 2) Whether Taiwan's present legislation on referendum is satisfactory. Though a referendum may seem like a good way for society to seek dialogue and consensus, it might be unable to effectively resolve the dispute and might even widen the gap further. It seems that the people of Taiwan have made a decision with their votes, but contrary to optimistic expectations, whether the controversy is ended or not is still an open question. The present result might not guarantee human rights protection, justice might not be served, and social equality might not be promoted.

\section{Overview of Referendum Law in Taiwan}

\subsection{Sources of law}

Referendums in Taiwan are grounded in its democratic constitution which grants people the rights of referendum and initiative to exert direct power in relation to "public policy" or “political decision” (李惠宗, 2015). Article 17 of the Constitution" says that "The people shall have the right of election, recall, initiative and referendum", and clearly specifies that people have the right to participate in a vote, to recall misbehaved administrative officials, to initiate laws, and to make important national decisions.

At first, although people had the rights to directly participate in politics in national or local matters as provided by the Constitution, there was no complete system regulating referendum or initiative regarding national or local matters until the adoption of the Referendum Act. In the 1990's, democracy in Taiwan entered a new chapter. Not only the "Temporary Provisions Effective During the Period of National Mobilization for Suppression of the Communist Rebellion $^{8}$ " as well as affiliated authorities were abolished, but all seats in Legislative Yuan ${ }^{9}$ were opened to common suffrage. This progress in democracy strengthened the public request for referendum. Since the first proposal of the Referendum Act in March of 1991, many other proposals were put forward, none of which however were passed (林建地, 2006). Not much was achieved during that period. Even so, referendums "without legal references" were continuously carried out and in 2003, the Referendum Act was presented again, and in January of 2004, became officially effective.

\subsection{Voting system}

In 2008, four years after the adoption of the Referendum Act, there had been only 3 national referendum with a total of 6 proposals. Although in these cases the number of positive votes was far greater than the number of negative votes, the threshold of more than half of the population with suffrage rights was never achieved. As a result, all 6 proposals failed (蔡雅瀅, 2014). It was deemed that these early referendums faced many systematic obstacles that were not beneficial to the system of direct democracy, such as the exorbitant threshold for

\footnotetext{
${ }^{5}$ Held simultaneously with the 2018 Taiwan's election of local public officials, with a total of ten referendums categorized into: anti-air pollution, anti-coal power, anti- food from nuclear disaster areas, anti/pro-LGBT rights, change of name (representation) at Tokyo Olympics, and nuclear green.

${ }^{6}$ Those proposals should be passed with more than 4,939,267 votes, since the number of participants in this referendum was 19,757,067. (With regard to the result of voting in a proposal of referendum, if the valid positive ballots are more than negative ballots and reach a total $1 / 4$ of the number of votes, the proposal is adopted. If the valid positive ballots are less than negative ballots or do not reach that fraction of the votes the proposal is rejected.)

${ }^{7}$ Constitution of the Republic of China (Taiwan), https://law.moj.gov.tw/ENG/LawClass/LawAll.aspx?pcode=A0000001, accessed 13 Auguest 2020.

${ }^{8}$ Temporary Provisions, http://www.taiwandocuments.org/constitution07.htm, accessed 13 Auguest 2020.

${ }^{9}$ The unicameral legislature in Taiwan.
}

68 
proposal, countersignatures, and voting, etc. Therefore, the government announced the amendments of the Referendum Act in January 2018.

Some of the key amendments ${ }^{10}$ include: reducing the voting age to 18 ; a tremendously lowered threshold for proposal, countersignatures, and voting; abolition of the Referendum Review Committee; change of the competent authority to the Central Election Commission for national referendum; giving the Executive Yuan ${ }^{11}$ the right to initiate a referendum proposals; and the establishment of electronic initiation and countersignature system all of this in the hope of stronger public political participation, emphasizing the importance of making people participate in legislation, and of deepening the influence of democracy in Taiwan. A short schematic presentation of the present revised referendum system can be found in annex A.

\subsection{Effects of a passed referendum}

What are the effects of a passed referendum, how much and to what does it bind the government? According to Article 30 of the Referendum Act "12 "1) For a proposal of referendum of law or autonomous regulations ${ }^{13}$, the original law or autonomous regulations shall lose its force from the third day counted from the day of public notice; 2) For a proposal of initiative of the legislative principles for law or autonomous regulations, the Executive Yuan or the municipal or county (city) government shall study a proposal of the related laws or autonomous regulations within 3 months, and send it to the Legislative Yuan or the municipal or county (city) council for deliberation. The Legislative Yuan or the municipal or county (city) council shall complete the procedure of deliberation before the adjournment of the next session; 3)For a proposal of referendum of an important policy, the President or the authority shall take necessary disposition to realize the content of the proposal of referendum; 4) For a referendum under the Constitution, the Legislative Yuan shall consult the President for publication". As we can see a passed referendum can have important consequences and binds the legislation to at least take into account and act upon the people's proposal.

Furthermore, paragraph 2 of the Referendum Act states that: "1) The initiated legislative principles shall not be altered by the legislative agencies; the law or autonomous regulation shall not be amended or rescinded within 2 years after implementation; 2) The same law cannot be enacted by the legislative agencies within 2 years after the rescission of the law or autonomous regulation through referendum; 3) For major policies made through initiative or referendum, the administrative agencies shall not alter administration of the proposal of initiative or referendum". Also, in Article 32: "No more proposals may be raised for the same matter within 2 years commencing from the day when the competent authority publicizes the result of voting". In other words, the government is bound for at least 2 years not to take any action that goes against a successful referendum

Finally, if the principal proposer considers that the new law does not fit with the result of the referendum or is doubtful that new law might violate the Constitution, a petition for interpretation of constitution by Justices of Constitutional Court may be filed. That is to say, the aforementioned 2 years of restraint only applies to legislative and administrative agencies, but not the Justices of Constitutional Court. New laws made as a result of a successful referendum can be challenged in Constitutional court at any point in time.

\section{Human rights issues involved in the "Love home Referendum"}

After the proposal of the "Love home referendum" were made, controversies over various issues arose. It was asked, "can a proposal that goes against the human rights be a referendum?" and "can an unconstitutional proposal be a referendum?" The two questions involve the issues of the relationship between referendum, human rights and the place of constitutional review.

\subsection{Can human rights issues be a referendum?}

The human rights mentioned in this discussion refer to "equality" and "marriage" as basic human rights.

10 Amendment of Referendum Act revises the full text of 56 Articles, https://aw.judicial.gov.tw/LAWENG//FLAW/dat02.aspx?lsid=FL027937; another amendment of partial Referendum Act articles were promulgated on June 2019, https://www.cec.gov.tw/english/cms/rProfile, accessed 13 Auguest 2020.

${ }^{11}$ The executive branch/cabinet in Taiwan.

${ }^{12}$ Referendum Act, https://law.moj.gov.tw/ENG/LawClass/LawAll.aspx?pcode=D0020050, accessed 13 Auguest 2020.

$\left.{ }^{13} 1\right)$ Article 25 of Local Government Act: Special municipalities, counties/cities, and townships/cities may, in accordance with law or upon authorization from higher government levels, formulate self-government ordinances and regulations. Self-government ordinances and regulations passed by the local legislative body and promulgated by the administrative body shall be called self-government ordinances; those formulated and promulgated or announced by the local administrative body shall be called self-government regulations.

2) Article 1705 of Constitution of the Republic of China (Taiwan): The term "law", as used in this Constitution, shall denote any legislative bill that shall have been passed by the Legislative Yuan and promulgated by the President of the Republic. 
As far as jurisprudence is concerned, the fundamental rights guaranteed by the Constitution cannot be taken away or reduced by the referendum procedure ${ }^{14}$. The freedom of marriage of gay citizens should have "equal protection" and is affirmed as a basic right by the Explanatory Ruling of the Justices. Some people thought that the marriage definition and special law referendum proposed by the anti-gay party were questionable because they constituted an attempted violation of human rights. However, according to Interpretation No.748, a special law also belongs to the scope of law formulation. Therefore, the content of the referendum proposal: protecting same-sex marriage through a special law, could be accepted as consistent with the procedure of referendum. Furthermore, any law established according to the result of a referendum can be challenged in the Constitutional court. Judicial Yuan's interpretation can be requested if there is any concern of constitutional violation after the law is established. If the law is determined as going against human rights, it might mean the referendum also did contradict human rights. No matter what the situation is, it is only possible to implement an investigation once the law is established.

According to Article 2 of the Referendum $\mathrm{Act}^{15}$, the referendum is applicable to matters apart from those stipulated in the Constitution. Nevertheless, any referendum proposal may involve the basic rights mentioned in the Constitution. Along with the development of human civilization, the connotation of human rights will also changes with time and public opinion, whether it is natural rights or legal rights. If the rights are changeable in this way, then resorting to referendums to modify them may have a certain degree of appropriateness (吳庚\&陳凉文,2016).

Finally, it should be remembered that the Constitution of the Republic of China does not explicitly stipulate that the right of marriage is a basic human right, and countries all over the world have no clear view whether "marriage rights" are basic human rights (Tettinger \& Geerlings, 2005). Interpretation No.748 does not directly define marriage or use the word "same-sex marriage". Thus, whether raising in a referendum this issue, that may involve major institutional changes to the marriage system, contravenes basic human rights is indeed a vague question when formulated in terms of "marriage rights".

\subsection{Does the definition of marriage in referendum C 12 contradict the Interpretation No.748?}

When the CEC accepted referendum Case 12, some people doubted whether the referendum proposal contradicted the interpretation of the constitution by the Justices. This led to a discussion as to whether an unconstitutional proposal can be accepted as referendum question and if the CEC should carry out a constitutionality review of proposals before accepting them. Many equal-right marriage supporters called for the CEC to reject the proposal.

From a procedural point of view, according to Article $10^{16}$ of the "newly amended Referendum Act ${ }^{17}$ ", there will basically only be a "formal review" by the CEC. That is, proposals can only be reviewed for technical issues such as the format of the proposal, the writing style and similar points, rather than the "content". Thus, although the constitutionality of a proposal may be doubtful, no constitutionality review can be carried by the CEC. As long as the proposal complies with specifications of Article 10 of the Referendum Act, it can be received.

Actually, this problem is closely related to the previous one. If Interpretation No.748 makes room for such a solution then asking the question clearly cannot be against the constitution. Furthermore, it seems likely that some referendum question could if successful lead to changes to the constitution, and such proposals will most likely always be "unconstitutional" by definition.

\footnotetext{
${ }^{14}$ Human rights are involved in almost every bill that relates to people's rights and obligations. For instance, "laborrights" are involved in the Labor Standards Act. If no referendum can concern any issues related to human rights, there will be a few issues that can be addressed in a referendum. "Human rights cannot be voted" is quite a simplified expression. Indeed, the relationship between the referendum and human rights should be that "human rights cannot be denied by referendums; but they can be established and guaranteed by referendums".

${ }^{15}$ Referendum Article 2, https://law.moj.gov.tw/ENG/LawClass/LawAll.aspx?pcode=D0020050, accessed 21September 2020.

${ }^{16}$ Referendum Article 10, https://law.moj.gov.tw/ENG/LawClass/LawAll.aspx?pcode=D0020050, accessed 21September 2020.

${ }^{17}$ On Dec $12^{\text {th }}$, 2017, The Legislative Yuan passed amendments to some provisions of the Referendum Act, abolishing the Referendum Review Committee of the Executive Yuan and replacing the review of the People's National Referendum Proposal by the Central Election Committee. The voting age was reduced from 20 to 18 years old. The threshold of the referendum proposal was reduced from 5/1000 of the vice-presidential electorate to $1 / 10000$. The threshold for the petition was reduced from $5 \%$ to $1.5 \%$ with the addition of electronic petition. The threshold for the passing of the referendum was reduced from $1 / 2$ of the total electorate to $1 / 4$, having the valid positive votes exceeding the negative votes. In addition, the non-residential voting is applicable in the national referendum, but the legislation must set the implementation method. The referendums of constitutional amendment bill and the territory change bill are collectively known as the "constitution referendum bill" (the amendments to the two laws need to be voted on after the amendment bill provisions are amended - procedure: consent for amendment $\rightarrow$ draft $\rightarrow$ referendum). It is limited to the proposal only of the Legislative Yuan. Also, the Executive Yuan may, after approval by the Legislative Yuan, propose a major policy initiative or referendum.
} 
In addition, it is always the case that judicial review can be carried out on any law based on a successful referendum proposal. Given this there seems to be little reason for the CEC to review referendum proposals in advance. Moreover, the authority of judging the constitutionality of any law or proposal should only rest with the Constitutional court. Giving CEC the authority to review the content of proposal for its constitutionality would be equivalent to making it an alternative constitutional court. It seems then that CEC should not possess the authority of in-advance review.

The review of the constitutionality is different from the issue of human rights. Unconstitutionality can be reviewed, but the unconstitutional review power are exclusive to the Justices and only for existing regulations.

\subsection{Freedom of speech, hatred or discrimination?}

Since the freedom of expression is one of the fundamental human rights, the initiative of "Love home referendum" is legitimate under such freedom as well. However, "speech" is also one of the main ways in which society constructs a "stigma-picture" (Anthony, 2006). The most common form of hate speech ${ }^{18}$ is to try to exclude certain $/$ minority groups and create a "stigma" identity to maintain the operation of a "hierarchy". The proposition of "Love home referendum" is of a kind that uses "speech form" to create and consolidate the "patriarchal system" and "heteronormativity", that make it difficult for LGBT groups to equally exercise freedom and fully participate in society. "Sexual-orientation-based hate speech" not only directly degrades LGBT groups, but also creates a hostile environment that can incite discrimination or bullying in society, suppressing these groups right to speak and making it easier to exclude them from legal protection. In the overall context of social inequality, the so-called "speech" might be a manifestation of power when everyone has the right to defame or deny a certain/minority group, advocating free speech at the same time. Meanwhile, this certain/minority group may be unable to fight back, and can only suffer the side-effect of this freedom of speech.

Each group should accept that a diverse society exists not only because we live for ourselves but also because we live for and with others. Therefore, everyone living their own life and doing things their own way should be able to have the "assurance" of not facing hostility, violence, discrimination or exclusion from others (許家豪,2018). However, different forms of hate speech undermine this public good, making it difficult to maintain "social tolerance". When a particular problem arises between the majority and a minority of unequal power, it is just always perfunctorily skipped over. This makes hatred and discrimination in daily life continue and to become ingrained in society.

\section{Flaws of Taiwan's Referendum Act}

\subsection{Compromising the effectiveness of referendum}

The Referendum Act in Taiwan nationally covers the law initiative and referendum, the development of legislative principles, or the initiative and referendum of major policies. The Amendment of Referendum Law passed in 2017, revised the previous "dual $50 \%{ }^{19 "}$ "thresholds to simple majority. The referendum is passed as long as the number of positive votes is greater than the negative votes, and that the number of agreeing votes reaches $25 \%$ of the electorate. This amendment, meanwhile, abolished the Referendum Review Committee. These changes made successful referendum easier, but greatly reduced the power of referendums. The required number of petitioners is fewer, thus making the passage of some proposals with few people easier. Referendum proposals consequently emerged endlessly, lowering the binding effect, escalating the people's distrust in referendums, and making it possible for laws or their formulation to be affected by the decisions of the minorities (Zimmerman, 1999). The numerous referendum proposals might make people more impatient about the referendums, which weakens people's attention on crucial issues.

\subsection{Conflict between proposals of referendums}

As the threshold of the referendum has been greatly reduced, it is easy for conflicting referendums to be passed together. At the proposal stage in this referendum, the pro-gay party proposed opposite proposals of to those presented by "Love home referendum".

\footnotetext{
${ }^{18}$ Hate speech in Taiwan, except for the circumstances that constitute a criminal offense of libel or public insults (there must be a specific victim), there is almost no relevant regulation and no specific countermeasure for those who stigmatize, insult, spread false information, and broadcast or publicly express statements that encourage hate and violence against specific groups (non-specific individua), such as homosexuals, transgender, etc. The author believes that freedom of speech is a basic right guaranteed by the Constitution and its importance is beyond doubt. However, like all basic rights, it has its limits. Especially for statements that may involve untrue, or words that imply discrimination and prejudice, even the ways of publishing that might incite hatred and violence. If it is completely left untreated, it will neither conducive to gender equality nor can really make a move to defend freedom of expression.

${ }^{19}$ The number of voters must exceed one-half of the total number of electors, and the number of valid votes must exceed one-half of the votes in favor.
} 
However, the CEC did not have the appropriate authority (the mandate to ask parties to correct their proposals by not contradicting each other, to have overall rational specifications for proposals or not submit proposals on the same topic by using different formulations of the same question.) when it came to proposals that could lead to mutually contradictory results. Nor does the Referendum Act have relevant provisions. Even though the actions taken by the CEC did highlight the democracy and openness of the referendum system, the issues were simplified.

However, if referendum proposals that contradict each other are both passed, the problem will be brought back to the original pending status. It is not only difficult for the government to make relevant decisions, but it is also a waste of time and government fund, and the fundamental social issue still cannot be handled effectively. Despite the fact that contradictory results that did not come out in this case, this is a problem that must be handled in future law amendments.

\subsection{Too many referendum proposals}

Apart from the various cases tending to same-sex marriage, the referendum this time also included 10 proposals ${ }^{20}$ on topics related to environment, food safety, and international politics. The numerous referendum questions not only prevented people from concentrating on and discussing the content for each topic to obtain a better understanding of what was involved, but also lead the public to ignore some of the topics and reduced the possibility of these topics being discussed. The premise of a referendum should be the full understanding of the topic by the public instead of voting blindly when it is time to vote. When everyone votes blindly without careful consideration, the result might only represent that most of the people do not care very much about the issue, independently of whether most votes support or reject certain proposals. It is thus questionable whether this kind of referendum result is really representative.

\section{Referendum and democracy}

If unanimity is the way of group life, the complexity of politics can no doubt be decreased. Possible conflicts caused by politics can as a result be significantly reduced. Yet, the reality is that differentiated and diverse opinions, propositions, or desires are the common to group life. Such differentiation means that for every opinion or dispute (apart from rare cases of perfect balance) there will be a dividing line between a majority and a minority. Any country can have opposing opinions between the majority and minority; however, political majority and minority are not necessarily identical with social majority and minority. Even when facing the same issue, the position of the majority and the minority can be inverted in time. Therefore, it is only by accepting and respecting the uniqueness and differences between each group can the goals of understanding each other and of giving to minorities the chance to express themselves be reached.

Voting and the subsequent division of the majority and the minority is the solution adopted when it is impossible to form a consistent uniform opinion. Majority rule thus constitutes the core element in modern democracy, but the rights and demands of the minority can as a result often be oppressed to some degree. For, if majority opinions are granted legitimacy, such legitimacy is not equivalent to accuracy(賴又豪,2019). As the government cannot reach absolute neutrality and fairness when faced with differences between groups, such difference must receive equal respects. Therefore, the demands from the minority are considered a part of "politics of difference".

One of the essential issues of modern-day democracy is to carefully consider the condition and fundamental rights of those "renegade and non-mainstreamed" minorities while nonetheless following majority opinions in a better way. It is only when the rights and freedoms of the groups we disagree with are fully respected and understood that suspicions and anxieties between different groups can be truly alleviated or eliminated. Therefore, in allowing minority groups to be truly accepted by society, the most important institutional factor is not the dominant power of the majority, but the right of protection of the minority group. The majority opinions in a democratic society has the power to act as well as the power to threaten. If we reduce different preferences to a fight in numbers, then the idea of majority rule will become equivalent to the idea that "power is justice". Therefore, the existence of an appropriate defense system for minorities is necessary. In other words, the constitution and personal rights protected by relevant laws are the systematic defenses that can prevent possible harms caused by majority rule, and the targets are every individual in society.

\section{Conclusion}

In a democratic society, when there is a lack consensus concerning the constitutional system and the fundamental social structure, such society can hardly be stable and risks being engulfed in a crisis of division.

However, while consensus is important, a mature democratic society must leave a room for objections and dissension from its members. Otherwise, the nature of democratic society as well as the inner motivation that drives it to grow will be lost.

${ }^{20}$ Referendum bulletin(ebook) of 2018, https://web.cec.gov.tw/preview/cms/29032, accessed 21 September 2020. 
Also, in order to make democracy functional, the most important factor is that the majority / minority division in politics and majority / minority in society do not coincide; they should be different (for example, the status of a person who belongs to the majority group in society does not necessarily receive the majority's political support) and ever-changing, otherwise, the majority rule might easily become a tyranny of the majority. Majority decision is a way of organizing government and deciding public affairs, but it should not be a way to cause oppression. In fact, there is or at least should not be any majority of fixed membership in a pluralistic and democratic society. There should be many "minorities", according to different policy issues. These minorities may form "alliances" for agreement and opposition, and larger "alliances" form the majority.

We think that the existing division between the majority and minority in Taiwan concerning the same-sex marriage issue raises problems of oppression and that compromise between different opinions is necessary. However, the accuracy of majority opinion is not guaranteed in democracy. In fact, all democratic governments lean toward majority rule, and this contains an inner risk. That of trying to extend the legitimacy of majority decisions to the level of the accuracy of decisions. The differentiation of the society must be maintained to some degree, but it cannot go too far. We must be prepared to tolerate (and even to respect) differences with which we may not agree, and thus understand and accept the differences between the majority and the minority.

If we cannot ensure that same-sex or other "marginal" groups are adequately tolerated and valued, various aspects of democracy, including referendum, can easily become a tool used by opponents to undermine their rights. Especially, given that people often recommend that making a decision via referendum when there are differences of opinion ensures a democratic result. However, if there are no external constraints and only the majority determines the rights on which a minority depends, the result may obviously be the tyranny of the majority over the minority, or vice versa. Nonetheless, without democracy, rights cannot easily be realized. What we need to think is that free, fair and square voting is important, but that it is not the only elements of democracy. "One person, one vote" is a means for a voting system to achieve a goal, not the goal itself. If the scrutiny of differences is only an attempt to find reasons for rejection, resistance, or even to aggrieve others, then the existence of differences itself becomes the cause of dissensions and oppression. Recognizing and tolerating differences within society and establishing reasonable safeguard mechanisms are the important affairs of a democratic society.

After several revisions, Taiwan's Referendum Act is finally set. Still, there are explicit flaws in the adopted articles. Are we actually returning power rights to people with this Referendum Act or are we turning it into a tool of the hegemonic majority? In view of the current circumstances, there are still many difficulties to be solved, before the right to referendum can fulfill its promise of an enlarged democracy.

\section{References}

Anthony, C. (2006). Opposing hate speech. CT: Praeger Publishers.

Central Election Commission, (2018),2018 年公投公報 [Referendum bulletin of 2018]. [Online] Available: https://web.cec.gov.tw/preview/cms/29032(September 28, 2020)

Central Election Commission, (2018),Form other than marriage to regulate same-sex unions referendum. [Online] Available:https://web.cec.gov.tw/central/cms/HearingNotice/27029(September 28, 2020)

Central Election Commission, (2018), Gender equity education referendum. [Online] Available:https://web.cec.gov.tw/central/cms/HearingNotice/27038(September 28, 2020)

Central Election Commission, (2018), The Marriage definition referendum. [Online] Available:https://web.cec.gov.tw/central/cms/HearingNotice/27003(September 28, 2020)

Central Election Commission, (2019),Referendums Profile. [Online] Available:https://www.cec.gov.tw/english/cms/rProfile(September 28, 2020)

Coalition for the Happiness of our Next Generation, (n.d.), 下一代幸福聯盟 (CHNG).[Online] Available:https://taiwanfamily.com/category/hearings(September 28, 2020)

Constitutional Court, Judicial Yuan, R.O.C, (2017),J.Y. Interpretation No. 748 【Same-Sex Marriage Case】 . [Online] Available:http://cons.judicial.gov.tw/jcc/en-us/jep03/show?expno=748(September 28, 2020)

Law and Regulations Retrieving System, JUDICIAL YUAN, (2019),Referendum Act. [Online] Available:https://law.judicial.gov.tw/LAWENG//FLAW/dat02.aspx?lsid=FL027937(September 28, 2020)

LAWS \& REGULATIONS DATABASE of The Republic of China, (1947), Constitution of the Republic of China (Taiwan).

[Online] Available:https://law.moj.gov.tw/ENG/LawClass/LawAll.aspx?pcode=A0000001(September 28, 2020)

LAWS \& REGULATIONS DATABASE of The Republic of China, (2016),Local Government Act. [Online] Available:https://law.moj.gov.tw/ENG/LawClass/LawAll.aspx?pcode=A0040003(September 28, 2020)

LAWS \& REGULATIONS DATABASE of The Republic of China, (2019),Referendum Act. [Online] Available:https://law.moj.gov.tw/ENG/LawClass/LawAll.aspx?pcode=D0020050(September 28, 2020)

Taiwan Documents Project, (n.d.),Temporary Provisions Effective During the Period of National Mobilization for Suppression of the Communist Rebellion. [Online] 
Available:http://www.taiwandocuments.org/constitution07.htm(September 28, 2020)

Tettinger, P. J., \& Geerlings, J. (2005). Ehe und Familie in der europäischen Grundrechtsordnung. EuR Europarecht, 40(4), 425.

Zimmerman, J. F. (1999). The Initiative: Citizen Law-Making. CT: Praeger Publishers.

賴又豪 (2019)。從民主觀點論全國性公民投票之合憲性控制一以少數群體權利保障為核心 [On the Constitutional Control of National Referendum: Striking a Balance between Democracy and the Protection of Minority Rights]。台北市：臺灣大學法律學研究所。

李惠宗 (2015)。憲法要義 [Constitutional Essentials]。台北市：昭明。

林建地 (2006)。公民投票在台灣之實踐與檢討 [The Practice and Modification of the Referendum in Taiwan]。 政治學學報, 6, 34-46。

許家豪 (2018)。性傾向仇恨性言論管制倡議 [Advocating Sexual-Orientation-Based Hate Speech Regulation]。台北市：東吳大學法學院。

蔡雅瀅 (2014)。公投法的回顧與展望 [Retrospect and prospect of the Referendum Law]。全國律師月刊, 12, 2-3。

吳庚、陳淳文 (2016)。憲法理論與政府體制 [Constitutional theory and systems of government]。台北市： 三民。

\section{Annex}

Annex A:

\begin{tabular}{|c|c|c|}
\hline Qualification & \multicolumn{2}{|c|}{$\begin{array}{l}\text { Any citizen of Taiwan of the age of } 18 \text { or more unless under the guardianship shall have the } \\
\text { right of referendum unless otherwise provided by the Constitution. }\end{array}$} \\
\hline \multirow[t]{3}{*}{ Referendum Items } & National & $\begin{array}{l}\text { 1) Referendum on laws; 2) Initiatives on legislative principles; 3) } \\
\text { Initiatives or referendums on important policies }\end{array}$ \\
\hline & Local & $\begin{array}{l}\text { 1) Reference to laws and regulations on local autonomy; 2) } \\
\text { Initiatives on legislative principles for laws and regulations on local } \\
\text { autonomy; 3) Initiatives or reference of important policies regarding } \\
\text { local autonomy }\end{array}$ \\
\hline & \multicolumn{2}{|c|}{$\begin{array}{l}\text { No proposal of referendum may be raised for any matters regarding budgeting, taxation, } \\
\text { salary and personnel affairs. }\end{array}$} \\
\hline \multirow[t]{2}{*}{ Initiation } & National & $\begin{array}{l}\text { 1) Initiated by people (the proposing population shall be more than } \\
1 \% \text { of the total electorate in the most recent election of President } \\
\text { and Vice President; the countersign population shall be more than } \\
1.5 \% \text { of the total electorate in the most recent election of President } \\
\text { and Vice President); 2) Initiated by Legislative Yuan; 3) Initiated by } \\
\text { Executive Yuan; 4) Delivered by the President (Defensive } \\
\text { Referendum }{ }^{21} \text { ) }\end{array}$ \\
\hline & Local & $\begin{array}{l}\text { Initiated by people (the proposing and countersign population shall } \\
\text { be prescribed by the Autonomous Regulations of the municipality } \\
\text { and county (city).) }\end{array}$ \\
\hline Execution & \multicolumn{2}{|c|}{$\begin{array}{l}\text { A referendum shall be held within } 1 \text { to } 6 \text { months after the announcement from central or } \\
\text { local election commission. If there is any national election during such period, the } \\
\text { referendum shall be held on the same day as the election. }\end{array}$} \\
\hline Result & \multicolumn{2}{|c|}{$\begin{array}{l}\text { 1) Passed: A referendum with a. more effective accepting votes than rejecting votes and } b \text {. } \\
\text { effective accepting votes exceeding } 1 / 4 \text { of the total population with suffrage rights. } \\
\text { 2) Not Passed: One of the above ( } a \text { and } b \text { ) conditions is not met. }\end{array}$} \\
\hline
\end{tabular}

\footnotetext{
${ }^{21}$ When the country is under the threat of foreign force and the national sovereignty is likely to change, the President may, by a resolution of the meeting of the Executive Yuan, put matters regarding national security to referendum.
} 